\title{
Railway Station Facilities in Rural and Urban Services Based on Observation and User Feedback
}

\author{
Mohd Idrus Mohd Masirin ${ }^{1, a}$, Ili Izzati Ahmad Fuad ${ }^{2}$ and Noor Hafiza Nordin ${ }^{2}$ \\ ${ }^{1}$ Smart Driving Research Center, Universiti Tun Hussein Onn Malaysia, 86400 Parit Raja, Johor, Malaysia \\ ${ }^{2}$ Faculty of Civil and Environmental Engineering, Universiti Tun Hussein Onn Malaysia, 86400 Parit Raja, Johor, \\ Malaysia
}

\begin{abstract}
Public transport is one of the facilities available in Malaysia. Overwhelming demand from the community has demanded public transport as an alternative for some people to do their daily activities. The increasing of Malaysian population brought many problems to the environment especially traffic congestion problem. The Government spends a lot of money to overcome this problem [10]. Public transport has been upgraded to ensure user comfort. Most people in the city are more interested in using railway transport as traffic congestion and travel time accuracy is better than other public transport $[1,5]$. To influence public demand, the facilities available at the train station should be complete [3,5]. The choice of location for the study are Batu Gajah station (station 1) and Kluang station (station 2) for rural services while Bandar Tasik Selatan station (station 3) and KL Central station (station 4) for urban services. The results of this study showed that, based on data and information obtained from field survey work and the feedback questionnaires from users, basic facilities at railway stations surveyed for urban and rural services can be identified and listed. An analysis of the status of the facilities at railway stations can be established through the safety of passengers and observations in the field. The facilities available at the urban service station are more complete than in rural service station. Facilities at railway station should be improved to attract people using the facilities.
\end{abstract}

\section{Introduction}

In Malaysia, public transport such as trains becomes an alternative transport to travel from one destination to another. There are many advantages by using public transport which is can reduce traffic congestion and increase the country's economy. Referring to the statistical population of Malaysia, in 1980s the number of population is about 18 million, and on 2013 the number of population has reached to 28.3 million. This number will continue to increase and it will cause many problems if there is no good traffic management and transport facilities [1,7]. Traffic congestion is considered one of the problems, especially in urban areas. Public transport such as train is able to create sustainable urban development where it can reduce environmental pollution [2]. This public transport can reduce carbon emissions and toxic gases. Tourist also use train as their transport due to the convenient and less expansive compared to other public transport. Safety of user should be emphasized by management to attract people to use train $[9,11]$.

\footnotetext{
${ }^{\text {a }}$ Corresponding author : idrusmas@gmail.com
} 
Railway facilities are important elements to attract commuters to use the rail services [6]. Passengers perceived that rail services are considered safe if the facilities are adequate and easy to access. Facilities in trains and stations are necessary to assist operators in providing good services. Elements that may affect quality train services are in-train facilities, station facilities, operation, maintenance and policies. In-train facilities will contribute towards passenger comfortability such as the provision of information, facilities in the coaches, safety, thermal comfort and technical elements during operation [5]. These factors are similar in urban and rural areas but with different approach and outlooks $[4,8,12]$. A good rail transit station should be able to make passengers feel comfortable and safe when they are at the station awaiting the train. Thus, it is important to provide and ensure that the railway station facilities are always audited, maintained and upgraded from time to time. However, in planning, it is easy to identify and suggest an ideal railway station facility and design but, several constrains and challengers such as financial, policies and procedures may dampen the realization of a good proposal for construction of a railway station [13].

\section{The Research Methods}

The research methodology is the most important aspect in a study. The results of the correct selection method will facilitate the search for information to carry out this study. There are many approaches that should be taken. Apart from literature review, on-site monitoring is important to get a more accurate analysis results. Additional information is also needed, such as journals, reference books, the internet, newspapers and others to provide more approaches to the study. Literature review is used to increasing understanding of the comparative facilities of the in urban and rural services. Site observation method and questionnaire method is used to achieve the objectives.

Several problems can be identified from site observation method. Through these problems, researchers can get a solution to overcome the problems. The researchers could identify the type of facilities available at the train station for rural services and urban services. 4 stations are selected for this study, where two stations for urban service and two stations for rural service. Station for rural services are Batu Gajah station (station 1) and Kluang station (station 2) while station for urban services are KL Central station (station 4) and Bandar Tasik Selatan station (station 3). Each station has different facilities. 6 elements needed to assess the facilities at train station which are information, safety, service, emergency, comfort and ventilation system. The objective of this study is to identify the basic facilities at the train station for urban services and rural services. To achieve this objective, observation form is needed. The purpose of this form is to facilitate the process of analyzing the study.

The questionnaire method was conducted in order to obtain information from users of railway services [3]. The questionnaire was based on objective of the research. Several questions which is related to the facilities at the railway station need to be answered by the respondents. Each respondent was asked the same question. Therefore, the comparison can be made between a respondent to another respondent. This is an effective method because the data could be obtained quickly. Questionnaires were distributed to 100 sets at the train station in the rural areas. The questionnaire is divided into seven sections. Part 1 is consisting of respondent information. Meanwhile, part 2 consists of four questions that involve information related question. Part 3 contains three questions that involve security related questions. Service related questions were asked in section 4 which containing 7 questions. 4 questions were asked in section 5 which are emergencies related question. 6 questions were asked in section 6 which are comfort related question. Section 7 contains two questions related to the ventilation system.

\section{Results and Discussion}

Observations work was done by researcher using observation form. It is to determine the facilities based on users safety and comfort at train station. 6 elements needed to assess the facilities at train station which are ventilation system, information, safety, emergency, comfort and service. The numbers of respondent for the elements were then converted to percentages to identify the 
composition of the feedbacks during the observations. It is considered easier to conduct analysis and to determine the majority opinions of the respondent.

Figure 1 showed percentages of signage at stations 1 and 2 are $25 \%$, while at stations 3 and 4 are much higher which are $35 \%$ and $80 \%$. Percentage of the board was higher at station 3 and 4 which are $50 \%$ and $80 \%$ compared to station 1 and 2 which are $50 \%$ and $40 \%$. The percentage of signboards also shows that the rate of rural services are low which $40 \%$ at stations 1 and $30 \%$ at station 2 compared to urban service station which is $50 \%$ at station 3 and $90 \%$ at station 4 . Percentage of visual notice board also show high percentage at station 3 and 4 which are $50 \%$ and $80 \%$ compared to the percentage of stations 1 and 2 which is $40 \%$ and no visual notice board found in station 2 .

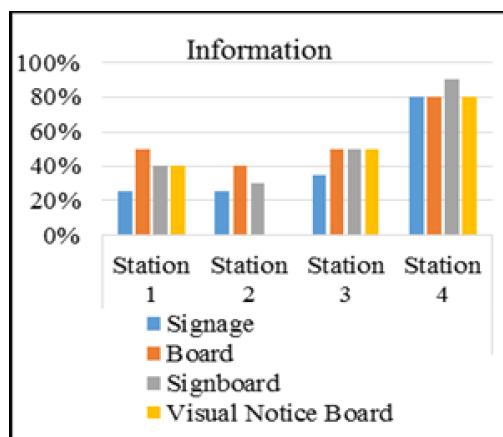

Figure 1. Graph percentages of information facilities at stations.

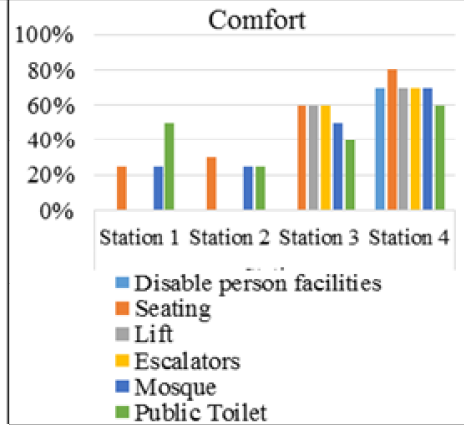

Figure 2. Graph percentages of comfort facilities at stations.

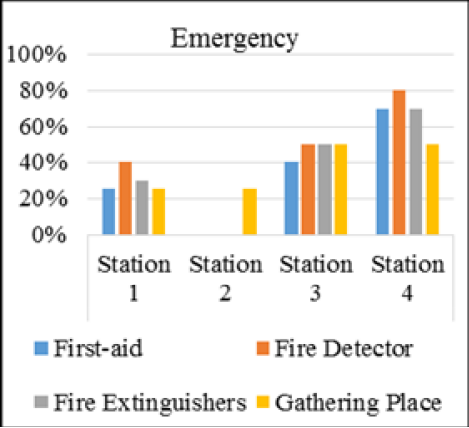

Figure 3. Graph percentages of emergency facilities at stations.

Figure 2 showed facilities for disable person only available at station 4 with percentage $70 \%$. Seating showed low percentage at stations 1 and 2 which are $25 \%$ and $30 \%$ compared to station 3 and 4 which are $60 \%$ and $80 \%$. Lifts and escalators only allocated at station 3 and 4 , which are $60 \%$ and $70 \%$. In addition, the percentage of mosque facilities at stations 1 and 2 is also lower than the percentage at stations 3 and 4 . The percentage of the public toilet facilities at stations 1 and 2 are $50 \%$ and $25 \%$ compared to the percentage of stations 3 and 4 , which give a high percentage. In addition, the percentage of parking is also high at station 3 and 4 exceed $50 \%$ compared to the two other stations. This because this station $(3 \& 4)$ are the interchange station for 2 lane which are LRT, KTM. The percentage of first-aid facilities in Figure 3 showed a high rate at station 3 and 4 which are $40 \%$ and $70 \%$ compared to station 1 which is $25 \%$ and no first aid facilities provided at stations 2 . The percentage at station 1 and 2 for fire detector is lower than the percentage at station 3 and 4 which are $50 \%$ and $80 \%$. The percentage of fire extinguishers at station 1 and 2 are also lower which are $30 \%$ and it was not provided at the station 2 while at station 3 and 4 give a high percentage which are $50 \%$ and $70 \%$. Percentage of gathering place was also high at station 3 and 4 , with a percentage of $50 \%$ compared to $25 \%$ of the station 1 and 2 . The percentage of closed-circuit camera at station 1 and 2 in Figure 4 showed a low rate of $25 \%$ at station 1 and there is no closed circuit cameras at the station 2 were found showed in Table 6 . Station 3 and 4 are higher which are $40 \%$ and $80 \%$. The police officer was found at station 1 and 2 are $25 \%$ for both stations compared to station 3 and $4,25 \%$ at station 3 and $80 \%$ at station 4 . Figure 5 showed the percentage of ticket counter facilities give a high percentage at station 3 and 4 which are $60 \%$ and $80 \%$ compared to station 1 and 2 which are $40 \%$ and $20 \%$. Customer service also give low percentage at station 1 and 2 which are $50 \%$ compared to station 3 and 4 which are 50\% and 75\%. In addition, the automated teller machines also available at station 4 , with $75 \%$ percentage. Kiosk and business facilities only available at station 1 with a percentage of $25 \%$. For urban services, station 3 and 4 give a high percentage of $50 \%$ and $80 \%$. Many bins available at urban services with $60 \%$ percentage at station 3 and $80 \%$ at station 4 compared to rural services with $30 \%$ percentage at station 1 and $35 \%$ at station 2 . Locker and ticket vending machine are available at station 4 with $90 \%$ and $75 \%$ percentage. Figure 6 showed the percentage of fan facility at 
station 1 and 2 are low which are $40 \%$ and $25 \%$ compared to station 3 and 4 , which showed a high percentage rate which is $50 \%$ and $80 \%$. In addition, air conditioner is only available at station 4 .

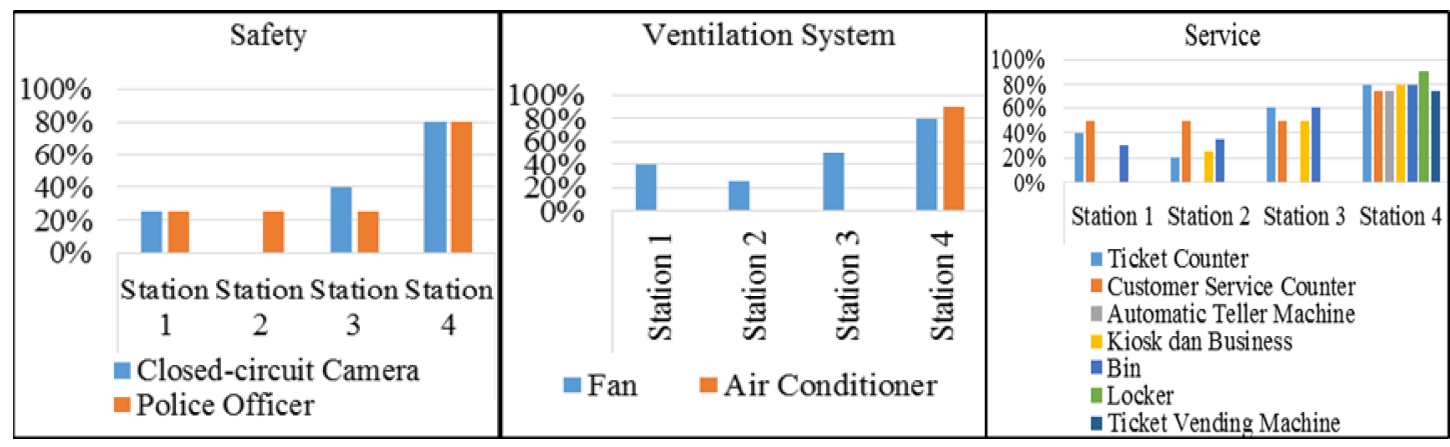

Figure 4. Graph percentages of safety facilities at stations.
Figure 5. Graph percentages of services facilities at stations.
Figure 6. Graph percentages of ventilation system facilities at stations.

User Feedback on urban services demonstrates a better percentage than rural services. Many of the respondent from urban services state that the information at the station is easy to understand, easy to get the information, the location of the information facilities are at the right place and the information given is correct as showed in Figure 7. From the graph in Figure 8, an urban service is more comfort than rural services. This is because urban services station has enough seating, more facilities for disable people, provide more facilities for toilet and mosque.



Figure 7. Comparison of information facilities in urban and rural area.
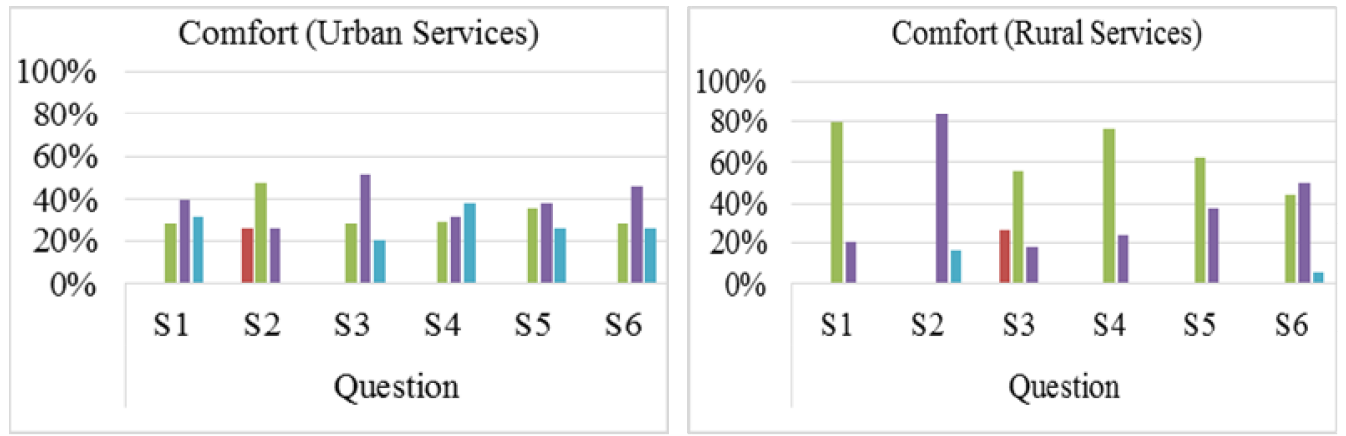

Figure 8. Comparison of comfort facilities in urban and rural area. 
Facilities for emergency are better at urban services station as showed in Figure 9. Some of the respondent disagrees about the gathering place at rural services station. This is because the location is not suitable.
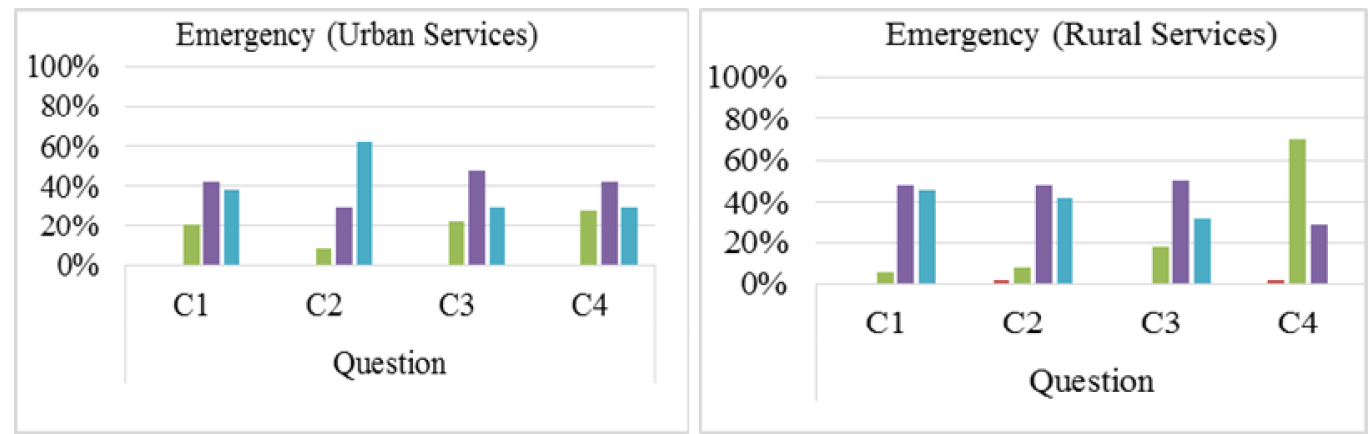

Figure 9. Comparison of emergency facilities in urban and rural area.

From Figure 10, it can conclude that the safety at urban services station is much better than in rural services station. Many facilities are available at station for urban services such as closed-circuit camera, and police officer. Through the questions contained in the service element, clearly showed in Figure 11 that station for urban services is much better than rural services. The analysis from Figure 12 showed that the ventilation system at station for urban services is much better than station for rural services. This is evidenced by the percentage of respondents who rate the highest ranking for urban services. Many respondents are not satisfied with the ventilation system and the respondent feel uncomfortable at station for rural services.
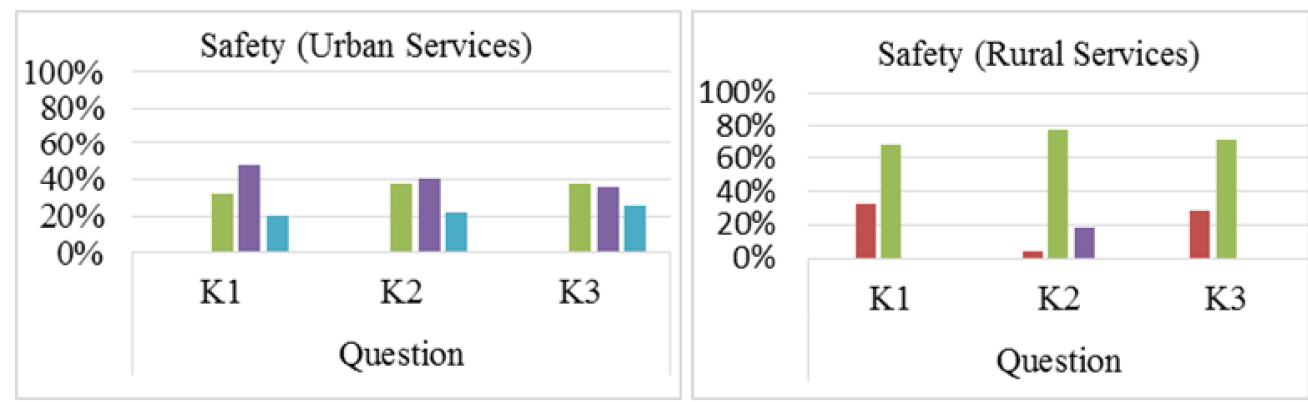

Figure 10. Comparison of safety facilities in urban and rural area.


Figure 11. Comparison of service facilities in urban and rural area. 


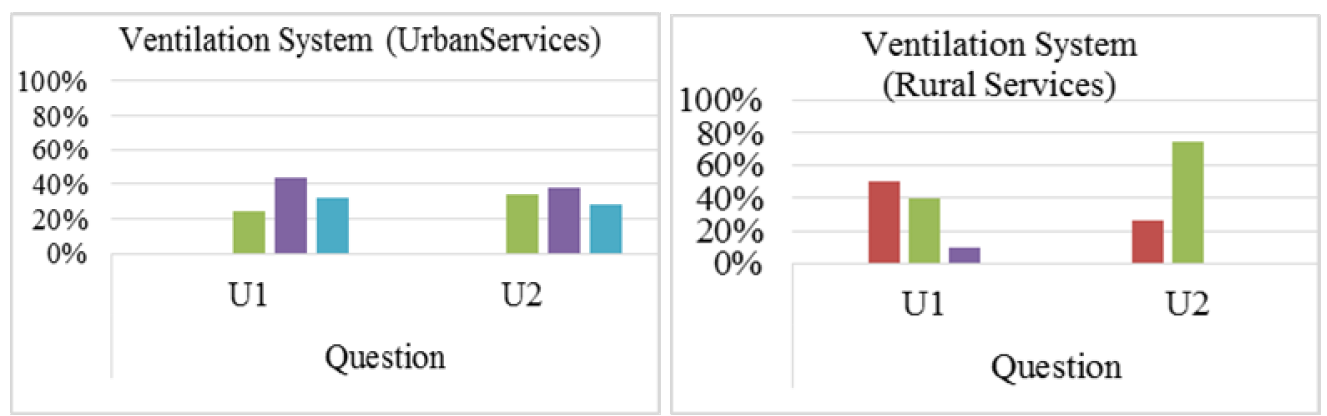

Figure 12. Comparison of ventilation system facilities in urban and rural area.

\section{Conclusions}

This study can provide a lot of advantages and benefits to the community. It was found that facilities available at the train station were not adequate and some users were uncomfortable with the conditions. However, the facilities at the railway station can be improved and maintained. Improvement of facilities at the railway station can be done if the operation management focuses on safety and comfort of users. Train services will improve thus can attract people to choose train as their daily transport. Through the data analysis, it was proven that facilities at the urban and rural services station have different facilities. Researchers also found that the train stations for urban services have more facilities train station for rural services. These differences were found due to the demand levels of the service, the location of the stations and the landscape around the stations. Thus, when constructing a train station considerations were not focused only on budget and design but also on the surrounding landscape of the stations.

\section{References}

[1] Ibrahim, Penduduk Malaysia Kini 28.3 Juta, Berita Harian, 29 Julai, (2011).

[2] M.S. Mohd Zakaria, Kajian Perbandingan Prestasi Operasi Monorel dan Keretapi Aliran Ringan (LRT) Bagi Penilaian Kualiti Perkhidmatan (QOS) Transit, Degree Thesis, Universiti Tun Hussein Onn Malaysia, Johor, (2014).

[3] M.I. Mohd Masirin, N.F. Johari, N.H. Nordin and A.H. Abdullah, A field study on urban transits in City of Kuala Lumpur: Passenger views on train noise and vibration, Journal for Applied Mechanics and Materials, 773-774, (2015).

[4] F. Akabal, M.I. Mohd Masirin, Z.A. Akasah and M.M. Rohani, Review on selection and suitability of rail transit station design pertaining to public safety, International Integrated Engineering Seminar, Batu Pahat, (2014).

[5] N.H. Nordin, M.I. Mohd Masirin, M.I. Ghazali and M.I. Azis, Appraisal on rail transit development: Train services and safety, International Integrated Engineering Seminar, Batu Pahat, (2014).

[6] V. Vuchic, Urban Transit: Operation, Planning and Economics, John Wiley, New Jersey, (2005).

[7] G. Li and C. Toda, Discussions on the local rail transit system in the urbanization, The 9th International Conference on Traffic and Transportation Studies, 193-198, (2014).

[8] Black, Rural communities and sustainability, in Cocklin, C. and Dibden J. (Eds) Sustainability and Changes in Rural Australia, University of NSW Press, Sidney, (2005).

[9] W. Village, Train station as places for community wellbeing, (2006).

[10]C.F Huang and Y. Xia, Research on the role of urban rail transit in promoting economic development, International Conference on Green Buildings and Sustainable Cities, 520-525, (2011). 
[11]Victorian Rail Industry Operators Group Standards, Railway Station Design Standard and Guidelines: Revision, (2011).

[12]M. Goggln, Design Guidelines: Guide to Station Planning and Design, Network Rail, (2011).

[13]N. Mohajeri, G.R. Amin, Railway Station Site Selection using Analytical Hierarchy Process and Data Envelopment Analysis, 107-114, (2010). 